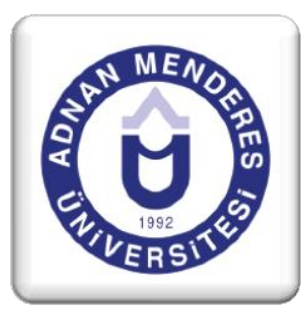

\title{
Yeni Biçimlenme Süreci Olarak Kültürel Miras
}

\section{Cultural Heritage as a New Formation Process}

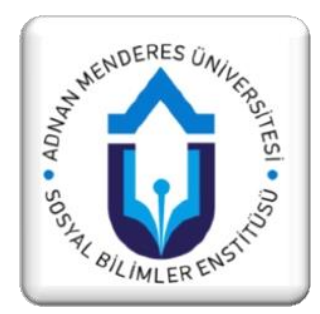

Gökçe ŞİMŞEK ${ }^{12}$

\section{$\ddot{O z e t}$}

Son yllarda, uluslarası platformda kültürel miras ve koruma anlaylşında değişimler izlenmektedir. "Kültürel miras" kavramı günümüzle ilişkilendirilerilerek yeniden tanımlanmakta ve mirasın günümüzdeki kullanımları ve rolleri açılanmaktadır. (Lowenthal, 1998; Harvey, 2001; Graham, 2002; Graham, Ashworth and Tunbridge, 2000; Smith, 2006) Miras, çağdaş sosyo-kültürel bağlamda geliş̧tirilen ve değiştirilen kültürel bir süreç olarak görülmektedir. Smith'e göre bu süreç, özellikle sosyal, politik ve dini açıdan egemen kurumlar tarafindan temellendirilmektedir. Özellikle, UNESCO, ICOMOS gibi kurumlar yayınladlkları yasal dökümanlarla koruma ve kültürel miras alanında yaptırım gücünü sürdürmeye yönelik rol sergilemektedir. (2006: 113) Smith, bu belgelerin özellikle miras yapılart ve alanlarının korunmasin gerçekleştirmek için uzmanlart işaret ettiğini vurgulamaktadır (2006: 92). Faro Antlaşması ile herkesin yararlanabileceği ve zenginleşmesine katkıda bulunacağı yeni bir miras anlaylşı ortaya konur (Avrupa Konseyi, 2005).

Belirtilen kapsamda, bu makale süreç olarak "mirasın yapımı"nı anlamaya yönelik bir çabadır. Koruma ve kültürel miras alanında genellikle teknik olgular olarak görülen müdahalelerin, bu süreç içindeki rollerinin incelenmesi üzerine temellenmektedir. Önceki çalsşmalardan farkl olarak, arkeolojik yapıların kazı öncesinden günümüze geçirdiği değişiklikler detaylı olarak incelenerek bu sürecin tanımlanması amaçlamaktadır. Böylelikle, Efes antik kentinde Küretler Caddesi üzerindeki beş yapı üzerinden mirasın yeni yaşam döngüsü açılklanmaya çalışllacak ve böylelikle, miras yapım süreci yeniden değerlendirilmeye çalışllacaktır. Sonuç olarak, bu makale miras yapım sürecini, yeni biçimlenme süreci olarak ve müdahaleleri bu sürecin araçları olarak yorumlamaktadır. Özellikle, arkeolojik bilginin zaman içinde değişsebilirliği temel alındiğında, Venedik Tüzü̆̆̈̈̈nde (1964: madde 9) işaret edildiğinin aksine miras yapilarl ve alanlarinin korunmasinda ve yorumlanmasinda varsayıminin her zaman yeri olabileceğine vurgu yapllmaktadır. Bu çerçevede, neden uzman olmayanları ve toplumdaki diğer aktörleri bu sürecin dışında tuttuğumuzu bir kere daha düşünmemiz gerektiği işaret edilmektedir.

Anahtar Kelimeler: Kültürel miras, arkeolojik miras, süreç olarak miras, müdahaleler, yeni biçimlenme süreci.

\footnotetext{
${ }^{1}$ Assist. Prof. Dr., Department of the Art History, Adnan Menderes University, Aydin, Turkey

${ }^{2}$ Based on the PhD thesis entitled 'Interventions on Immovable Archaeological Heritage as a Tool for New Formation Process' conducted as part of the Restoration Program of the Middle East Technical University and supervised by Assoc. Prof. Dr. Emre Madran and Dr. Nimet Özgönül.
} 


\section{Abstract}

In recent years, the understanding of cultural heritage and preservation internationally has changed. The concept of heritage is explained in relation to its "presentness", and the roles and uses of heritage are described (Lowenthal, 1998; Harvey, 2001; Graham, 2002; Graham, Ashworth and Tunbridge, 2000; Smith, 2006). The heritage, which is always developed and changed according to the contemporary socio-cultural context, is a cultural process. For Smith, the ideas of dominant social, political or religious groups are explained by authorising institutions of heritage (2006: 30) and generally provide a philosophical basis for the process. In particular, authorised institutions, such as United Nations Educational, Scientific and Cultural Organization (UNESCO) and International Council on Monuments and Sites (ICOMOS) have enacted conventions, charters and other texts that play a role in the maintenance of authority in the discourse (2006: 113). Smith emphasizes that in these documents, the suitability of professional experts to care for and protect monuments and sites is signified (Smith, 2006: 92). Through Faro Convention, a new perspective in heritage based on the right of everyone, alone or collectively, to benefit from the cultural heritage and to contribute towards its enrichment (CE, 2005) is developed.

Within this scope, this paper represents an attempt to develop an understanding of how heritage is created. This attempt is based on an examination of the roles of interventions, which are generally viewed as technical issues within the field of preservation, throughout this process. Unlike previous studies, this paper attempts to analyse the process by examining archaeological edifices in detail, starting at the pre-excavation stage. Thus, a new lifecycle of heritage buildings is explained in relation to five archaeological edifices on Curetes Street at Ephesus. The process of heritage making is then re-evaluated. Consequently, this paper interprets a new life cycle of heritage as a "new formation process", and the interventions (which are presented under the topics of excavation, conservation, interpretation and presentation) are described as tools within this process. Because it has been shown in some cases that archaeological knowledge can be mutable with time, the interpretation and preservation of heritage buildings and sites can based on conjecture, which is contrary to the emphasis given in the Venice Charter (1964: article 9). In this respect, there is a great need to reconsider why non-experts and different actors in community are excluded from this process.

Keywords: Cultural heritage, archaeological heritage, heritage as a process, interventions, new formation process.

\section{Introduction}

In recent decades, a number of scholars within the interdisciplinary field of modern material culture studies have sought to explain the role of heritage (Smith, 2006; Harrison \& Schofield, 2010) and to theorise about the heritage concept in relation to its "presentness", its nature as a cultural and social construction, and its use as an economic resource (Lowenthal, 1998; Harvey, 2001; Graham, 2002; Graham, Ashworth and Tunbridge, 2000). For Harvey, heritage is a cultural process, and the concepts 
of heritage have always developed and changed in accordance with the contemporary socio-cultural context (2001: 15). This view-centring "process" and the importance of the contemporary sociocultural context in the theorisation of heritage is reiterated by Smith, who states the following:

"What makes these things valuable and meaningful -what makes them 'heritage', or what makes the collection of rocks in a field 'Stonehenge' - are the present day cultural processes activities that are undertaken at and around them, and of which they become a part. It is these processes that identify them as physically symbolic of particular cultural and social events, and thus give them value and meaning." (2006: 3)

The important point here is the recognition of the importance of value and meaning of the contemporary socio-cultural context as part this process. In contrast to the conventional emphasis on intrinsic values, values are placed on artefacts or activities by people, as mentioned by Graham \& Howard ${ }^{3}$. For Hardy, "...heritage is a value-loaded concept, embracing (and often obscuring) differences of interpretation that are dependent on key variables, such as class, gender and locality and with the concept itself locked into wider frameworks of dominant and subversive ideologies..." (1988: 333) Thus, heritage scholars have sought to place the contemporary socio-cultural context within the explanation of heritage.

From another viewpoint, some aspects of heritage and archaeology overlap, as mentioned by Harrison \& Schofield. In the context of the archaeology of the contemporary past, "archaeology is the creation of the past in the present through the process that draws on the material evidence that creates" (Harrison \& Schofield, 2010: 9). The study of the archaeology of the contemporary past overlaps with heritage through the idea of the "creation of the past in the present through the process". This study also overlaps with the approach taken in this paper, which attempts to understand the process in which heritage is formed and defined in order to turn our lens on the process of making "heritage" and to reassess what has been been practically done in the last century.

Another crucial issue in this process is the question of who it is that really acts. As Smith states, the ideas of the dominant social, political or religious groups are explained by the authorising institutions of heritage (2006: 30), generally providing a philosophical basis for the process. According to Smith, on the one hand, the authorising institutions of heritage, such as UNESCO and ICOMOS, have enacted conventions, charters and other texts that play a role in the maintenance of authority in the discourse (2006: 113) and a formal legal and policy process have been emerged in many Western countries (2006: 92). On the other hand, the foundational text for the principles of conservation and preservation, the Venice Charter, emphasising some concepts such as integrity' (article 14), 'aesthetic and historic values' (article 9) and 'respect for original material and authentic document' (article 3), signifies the suitability of professional experts to care for and protect monuments and sites (Smith, 2006: 92). In this context, the Faro Convention presents a new perspective for cultural heritage and defines cultural heritage as '.. a group of resources inherited from the past which people identify, independently of ownership, as a reflection and expression of their constantly evolving values, beliefs, knowledge and traditions' (2005, article 2). It emphasizes that 'everyone, alone or collectively, has the right to benefit from the cultural heritage and to contribute towards its enrichment' and 'everyone, alone or collectively, has the responsibility to respect the cultural heritage of others as much as their own heritage, and consequently the common heritage of Europe' (Faro Convention, 2005, article 4). For Fairclough, Faro defines cultural heritage as a resource that is used by people. He expresses that heritage objects are less important than the values attributed by people $(2012,36)$. For Dinçer and Enlil, Faro Convention signifies importance of being equally distant from all communities' heritage and promoting inter-religious dialogue $(2012,48)$. In this context, it is expected that this new perspective, which is not valid in some countries such as Turkey and UK (Fairclough, 2012, 36), will influence legal frameworks and practices.

In that respect, this paper represents an attempt to understand the process of making "heritage" by examining the roles of interventions. Many studies of heritage issues generally focus on the scope and various aspects of this process. By examining the process of defining heritage in detail, the paper seeks

\footnotetext{
${ }^{3}$ Heritage and Identity, From

http://www.lundhumphries.co.uk/pdf/SamplePages/Ashgate_Research_Companion_to_Heritage_and_Identity_Intro.pdf
} 
to identify what is changed and how it is changed, and how the process is shaped. In this context, the paper views this process as a "new formation process", by which heritage buildings and sites are redefined. This is particularly important when looking at the process of making "heritage". Consequently, this paper aims to view the process of making "heritage" as a new formation process and to view interventions as tools that frame and shape this process; this paper also questions, "Why should archaeologists be in charge of this?" To achieve these aims, the process will be examined using five case studies within the Antiquity site of Ephesus. The examination starts at the pre-excavation stage and is placed within an understanding of the changes caused by interventions. Achieving a deeper understanding of the nature of this process is important because it allows us to engage in debates regarding the mutability of archaeological knowledge and interpretations that are generally based on expert's views.

\section{Analysis: From Excavation to Interpretation and Presentation}

Throughout the last century, heritage discourse has constructed both theoretical and practical tools to legitimise its applications. Documents such as the Athens Charter (1931), the Venice Charter (1964), the Nara Document (1993), ICOMOS (1990) and Faro Convention (2005) identify the basis and theoretical background of this topic. Moreover, appropriate practices such as excavation, conservation, interpretation, presentation, management and some principles related to these practices are explained in these documents. These practices range from management to the use of techniques and from cultural practices to economic practices (Smith, 2006: 13). Among these practices, interventions on edifices and sites, which are based on the regulation of a range of values, and, of particular significance, directly change the characteristics and appearances of heritage buildings and sites. The interventions of excavation (1), conservation (2), and interpretation and presentation (3), are analysed here in an attempt to understand the changes in archaeological edifices and the nature and characteristics of the process of making 'heritage'.

To explore the interventions in detail, five archaeological edifices (Terrace House II, the so-called Hadrian Temple, the Trajan Fountain, the Celsus Library and the Memmius Monument) located on Curetes Street - one of the main axes within the city of Ephesus (Figure 1) will be examined starting at the pre-excavation stage. This analysis offers insights into the physical consequences of space, the expression of values, the roles of experts and the nature and characteristics of "the new formation process".

\subsection{Terrace House II}

Terrace House II, located at the southern end of Curetes Street (site no.1 in Figure 1), is an insulae containing seven residential units, which are distributed over a number of terraces (Krinzinger, 2000: 22). Before excavation, this area was almost completely covered with rubble deposits, and only some of the remains were visible, as seen in Figure 2a. The excavation of Terrace House II began in earnest after the discovery of the Sokrates painting, and huge rubble deposits were removed between 1969 and 1983 under the direction of $\mathrm{H}$. Vetters (Ladstätter, 2002: 13). The excavation revealed residential units that were arranged as individual rooms containing heating systems, latrines and running water centred around a central, open inner courtyard. The rooms contained niches that were covered with glass mosaics, and the walls were richly decorated with variously coloured marble panels and featured painted upper parts (Krinzinger, Outschar, and Wiplinger, 2000: 110). The architectural furnishings on the ground floor are of outstanding cultural and artistic importance in terms of quality, variety and unity, and the building elements reflect the artistic and aesthetic requirements and tastes of the occupants, as well as a high level of culture and an appreciation of art (Krinzinger, Outschar, and Wiplinger, 2000: 110), as shown in Figure 2b. The persityle hall, which contains an illusionistic painting of a garden and a central water fountain, is unique in Ephesus (Thür, 2005).

During excavation, great care was taken to conserve the fresco paintings, which were suffering deterioration (Dawid and Dawid, 1972-1975: 549); for this reason, the Socrates frescos were removed 
at the time of excavation (Krinzinger, 2002: 36). The building elements, such as the frescoes and glass mosaics, may be viewed as intrinsic elements of a contextual whole, and accordingly, a protective shelter was constructed at the end of 1960s to preserve the residential units and their interior decoration (Krinzinger, 2002: 36-39). Thus, one of the challenging issues in Ephesus emerged in order to preserve the residential units covering approximately 4,000 $\mathrm{m}^{2}$ (Krinzinger, 2000: 22).

Following this temporary construction, the roof, which was designed based on the ground plans of the original rooms, was constructed in the 1980s for residential units 1 and 2. However, contemporary approaches and the negative effects of the roof, such as its aesthetic quality, the climatic conditions it creates and the use of reinforced concrete, were among the reasons for interrupting its construction in 1986 (Krizinger, 2002). After this trial construction, an architectural competition to design a new protective shelter was launched. Providing the greatest amount of protection to Terrace House II with the absolute minimum of intervention in the material substance was the most important design criterion, and visitor access had to be maintained. (Schirmer,2000: 37) The new protective shelter, constructed using stainless steel and polycarbonate, was considered a good solution due to the advantages it offered in providing optimal ventilation and high aesthetic quality (Krinzinger, 2002: 36). For Ladstätter, this roof is not only a protective shelter for Terrace House II, but also it creates a museum for the site. The roof allows conservators to work on conserving the remains during entire year, regardless of weather condition; it also functions as a workshop and allows visitors to obtain information about ongoing research. (2012: 53) The placing of the glass and steel pathways was designed independently of the authentic circulation and spatial organisation of the residential units, thus creating a new effect on the visitor's experiences and perceptions. (Figure 2c)

In Ephesus, the protective shelter created for Terrace House II says something about how this building is preserved, conserved, interpreted and presented in a particular time. On the one hand, new developments in material and construction technology have allowed the construction of a shelter that provides optimal ventilation, a transparent appearance and a walkway constructed of glass and steel. On the other hand, the protective shelter represents a set of cultural characteristics, such as aesthetic taste and the choice of preservation approach. This choice also materially represents the images, thoughts and feelings of the people, especially experts, making the decisions. This means that Terrace House II, together with the protective shelter that covers seven independent residential units of Roman times and that creates a new spatial organisation and circulation, is not simply a representation of past human experiences; rather, it is the product of current human activities in Ephesus.

\subsection{The so-called Hadrian Temple}

The so-called Hadrian Temple, which is located on the western part of Curetes Street (site no. 2 in Figure 1), is a standing monument at present; the structure has a porch with a 'Syrian pediment' on the southern façade and a cella at the back and was completely covered prior to excavation in the 1950s (Figure 3a). Miltner, the director of the archaeological research, described it as a prostylos in antis and states that the architectural elements of the façade were nearly complete (Miltner, 1959: 264). The architect K. H. Gösch developed a project based on the re-erection of the structure as it stood at the end of the 4th century (Miltner, 1959: 373) (Figure 3b). Then, the porch and the cella were re-erected using the existing architectural elements, fragments and some additional materials. The columns supporting the porch were completed using concrete made with white cement in an attempt to match the colour of the original marble elements. The southern wall between the porch and the cella is constructed from rubble and is supported by concrete lintels at the back and covered with marble blocks at the front. In addition, the friezes have been reproduced in white cement to replace the original, damaged ones (Miltner, 1959: 373).

Although the so-called Hadrian Temple was re-erected, a variety of interpretations have been proposed since Miltner's interpretations. In the early 1990s, Outschar explains that the structure is a memorial for Hadrian`s companion Antinoos (Outschar, 1999: 443-48). For Outschar, due to its reliefs depicting the story of the foundation of Ephesus, scenes from the late Roman era, and images of the Tetrarchs, the so-called Hadrian Temple offers evidence of the '...integration of private and public attitudes in Imperial and late Roman Ephesus' (2000:118). For Aurenhammer, the frieze depicting 
scenes from the foundation legend of Ephesus found on the rear wall of the porch and the four plinths supporting the statues of the Tetrarchs are later additions (2005: 264).

However, in recent years, the contradictions between Miltner`s interpretation and the building inscription resulted in the initiation of a new project on the so-called Temple of Hadrian (Quatember, 2013: 218). The so-called Hadrian Temple was documented again by 3D scanning to provide data that could be used to answer complex architectural questions (Quatember, 2013: 218-227). In addition, the original interpretation that views the monument as a "neocorate temple" appears more than doubtful today. Quatember suggests that the structure does not represent a typical neocorate temple of the province of Asia. Instead, Quatember connects it with the Various Bath and interprets it as a quintessentially secular structure (Quatember, 2010: 379-394). In addition, a current intervention in 2014 indicates that the re-erected monument may need further repair some time after its re-erection.

The case of the so-called Hadrian Temple shows that approximately 55 years after its re-erection, some unanswered questions remain about its building history and architectural issues. Therefore, the production of archaeological knowledge has the potential to continue, even though the heritage building was interpreted according to the archaeological knowledge of a particular time. Thus, the socalled Hadrian Temple indicates that any meaning and message about heritage is not inherited; rather, it is based on the views and interpretations of some experts, and these views can change in time through new discoveries. The process through which the so-called Hadrian Temple has been redefined demonstrates that archaeological knowledge and history may change, although different stories have been told in the past. This case also indicates that the views of professional experts, who are assigned to care for and protect monuments and sites as stated in the Venice Charter (Smith, 2006: 92), can result in conjecture, contrary to the stated aim that, "it must stop at the point where conjecture begins..." (the Venice Charter, 1964: article 9), due to mutability of archaeological knowledge. The analysis of the so-called Hadrian temple draws attention to the possible contradiction between different emphases and their results, as mentioned in the Venice Charter. Moreover, the structure serves as a gigantic sculpture on Curetes Street at present (Figure 3c), the meaning and message of which has been re-interpreted again and again. Therefore, this is a process by which heritage buildings can be re-interpreted and re-intervened repeatedly.

\subsection{The Celsus Library at Ephesus}

The Celsus Library is located at the intersection of two main axes, Curetes Street and Marble Street, at the heart of the archaeological site (site no. 3 in Figure 1). The library forms the western edge of Library Square, which is connected to the Tetragonas Agora by its southern gate. The library stands on nine steps and is rectangular in plan, and its eastern façade is composed of alternately projecting and receding elements along two storeys and contains a burial chamber of Ti. Celsus Polemaenus.

Prior to Heberday's excavation in 1903, the library was completely covered. During the excavation campaign, Heberday discovered a structure that exhibited the characteristics of imperially decorated architecture and that bore evidence of re-use from the second post-Christian century, as shown in Figure 4a (Braun, 1953: 1). Two stone courses belonging to the imperially decorated structure were in their original location (Strocka, 1979: 812) and featured a fountain basin formed out of 'Parther reliefs' (Braun, 1953: 42). In the interior space, a row of columns and a pillar were discovered, which were viewed as evidence of later use. After being demolished during an earthquake, the openings of the façade were filled with rubble, and the façade became a background for the fountain in Christian times (Strocka, 1979: 814). There have been two proposals suggesting how the Celsus Library would have looked when first built: the first suggests that the interior space featured galleries along three storeys (Outschar, 2000: 132), whereas the second, developed by Hueber, suggested a two-story structure with façade characteristics and stone workmanship that resembled imperial structures in Rome (Strocka, 1979: 814-15). Among the ancient libraries, the Celsus Library is distinctive in terms of its façade characteristics and is a rare example of its type (Yıldız, 2003: 181). 
After a long period, a project with façade characteristics reminiscent of the Roman period was developed in the 1970s. The eastern façade comprised 80\% authentic elements (Hueber, 1978: 980), was re-erected up to two storeys in height, and the interior space was enclosed almost up to the beginning of the first storey in the 1970s. Today, the re-erected western façade of the library is a combination of various authentic elements and new materials, such as stone, brick and concrete. The resulting structure gives an idea of the spatial characteristics of the urban environment of Library Square as they appeared during Roman times and acts as a significant element and an attractive point within the ancient city of Ephesus in the present (Figure 4b). In addition, the Celsus Library has become part of the socio-cultural life of contemporary society by developing new uses. On the one hand, the hall of the library has been equipped with information panels housed within niches and has been turned into a kind of information centre for visitors. On the other hand, Library Square has been used for contemporary cultural activities, such as concerts and performances.

The Celsus Library, as an edifice and as a place, representing histories of multiple historical periods, has been physically altered and shaped by the decisions of experts and the archaeological knowledge of its time. The emphasis on the architectural features of the entrance façade has resulted in signifying the west façade consistent with the proposal suggesting how the Celsus Library would have looked when first built in Roman times. Thus, the manner in which an archaeological edifice is intervened refers to the way in which it is physically and conceptually shaped. Whereas the two-storey facade acts as an attractive centre within the site, the inner hall, acting as a kind of visitor centre, allows social interaction and relations to occur.

As a result, the Celsus Library, which has been physically altered and shaped in relation to the values and meanings of the experts, is in a state that it had never been in previously. Therefore, the library is a product of the present and past, in which architectural elements and fragments of past and new materials are joined through the views and meanings of experts of a particular time. Therefore, the Celsus Library (which was revealed in 1903 and re-erected during the 1970s), as one the representative buildings of Ephesus during the 2000s, is part of an ongoing process in which humans and the past interact in the present.

\subsection{The Trajan Fountain at Ephesus}

The Trajan Fountain, which is located on the western part of Curetes Street (site no. 4 in Figure 1), has a rectangular plan with a main pool surrounded by a columnar façade in a ' $U$ ' shape and with a narrow secondary basin running along the southern façade. This fountain was built at the beginning of the second century (between 102 and 104 AD) by Ti. Cladius Aristion and his wife, Iulia Lydia Laterane (Quatember, 2011: 100). According to the inscription on the frieze and on the architrave of the ground floor, the fountain was dedicated to Emperor Trajan (Thür, 2000: 116).

The Trajan Fountain was excavated in the 1950s. A structure with a plan framed on three wings and some column bases were discovered (Figure 5a). According to Thür, the building had a two-story columnar façade in the tradition of a theatrical scaenae frons with projecting side-wings (2000: 116). Various statues from different periods, including a male figure, a naked Dionysos sculpture and a giant statue of the Emperor Trajan, were found. For Aurenhammer, the existence of statues from different periods offers evidence that the structure underwent some modifications in late Roman times (2004: 273). Of the three fountain installations at Ephesus, only the Trajan Fountain was designed in the tradition of a theatrical scaenae frons with additional side-wings, which represents a particular type in Ephesus (Thür, 2000: 116).

In 1962, the fountain, which was most likely designed as shown in Figure 5b, was re-erected under the direction of Miltner (Keil, 1964: 122). The fragmented architectural elements are positioned in their original locations according to their place in the plan, without respect for the original scale or proportion, and the missing parts and elements were completed with concrete in simplified forms (Figure 5c) due to a lack of architectural fragments. During the 2000s, the Trajan Fountain was studied once again. The fountain façade is interpreted as the earliest known to date to have been privately financed and in which the donor couple was represented. The fountain is viewed as a representative building in the service of the self-expression of its donors, i.e., the married couple, Tiberius Claudius 
Aristion and Iulia Lydia Laterane. This structure is important as an example of a building type in which architectural type of the "nymph facade" is used for the self-representation of the Roman elite in Asia Minor during the Roman era (Quatember, 2011: 101-107).

Today, the observer can easily distinguish between authentic and new architectural elements in the Trajan Fountain. The façade is the product of the some main principles, such as stopping at the point where conjecture begins and to include a contemporary stamp in new parts (Venice Charter, 1964: article 9). Therefore, the Trajan Fountain represents both archaeological knowledge, which is produced by the experts of a particular time, and the common preservation approach of the 1960s, as codified in the Venice Charter. Currently, the Trajan Fountain does not act as a representation of the Roman elite as Quatember describes; instead, it acts as a representation of signified expert view and the technique and preservation approach of the 1960s.

\subsection{The Memmius Monument at Ephesus}

The Memmius Monument, which is located at the eastern end of Curetes Street, at the point where it connects to Domitian Square, was built in honour of C. Memmius in the third quarter of the first century. This monument has an almost square ground plan that is raised on four marble steps (Scherrer, 2004: 6). As shown in Figure 6a, a variety of architectural elements were discovered in the near vicinity of the Memmius Monument during excavation, including some architrave fragments bearing Latin inscriptions (Bammer, 1971: 11) and some blocks bearing images of the members of the Memmius' family and personifications of his characteristic virtues (Outschar, 2000: 96).

To date, two suggestions ${ }^{4}$ have been proposed regarding the original architectural design of the Memmius Monument. In the first conception, the Memmius Monument is a political symbol from the Roman period; this suggestion was proposed by Bammer (1973: 222). In relation to this emphasis, some architectural elements of the Memmius Monument were re-erected by Bammer in 1963-4 according to the restitution of this idea (Figure 6b). Bammer proposes a building one storey in height, rising on steps, and states that it would not be possible to restore the building to its original height (Bammer, 1972-1975: 393). Therefore, the existing architectural elements, which are far from complete, have been mounted on concrete blocks to re-erect the individual architectural elements. In the second conception, Outschar suggests a building two storeys in height that has a pyramidal cap at the top (1990: 57-85). The honorary building is thus interpreted as a mixture of western forms and traditional Hellenistic forms (Outshar, 1990: 83), represents both change and continuity in architecture.

At present, the Memmius Monument (Figure 6c) represents on the one hand the interpretation of the experts and the use of contemporary material and techniques during the 1960s. Similar to the so-called Trajan Fountain and the so-called Hadrian Temple, the example of the Memmius Monument indicates that the process of producing archaeological knowledge may continue, even though the monument has been interpreted, re-erected, and presented. This implies that the meaning that experts currently consider may change and that it sometimes does not lie in some meaning that it might have in the past.

\section{Findings}

A closer look at the interventions conducted on archaeological edifices indicates that the edifices, which are ruined and fragmented at the excavation stage, are reshaped and redefined through interventions that have been applied to preserve them. The five cases detailed above are just a few examples of what is widely seen in monuments and sites today and how archaeological edifices, as heritage sites, may be changed to become part of contemporary life. Other cases could be shown that demonstrate how heritage buildings and sites have been changed to different extents. However, these other cases would not change the overall picture. In this context, three things are clear. First, archaeological edifices that have remained buried for centuries become visible upon excavation and

\footnotetext{
${ }^{4}$ The initial proposal was developed by A. Bammer (FiE VII). The final proposal was developed by U. Outschar (Öjh 1990, 57-85).
} 
appear in a wide variety of physical forms, meanings and uses. Second, interventions overlap one another, causing changes in both the appearance and the meaning of archaeological edifices. Third, the production of archaeological knowledge may continue, even though the structure has been represented as a standing monument according to the interpretation of experts, such as archaeologists or heritage professionals. In accordance with these principles, no less than five discursive characteristics can be listed.

First, for heritage buildings and sites that have not previously been studied, scientific knowledge is produced thorough the process started with interventions. As shown in the cases mentioned above, archaeological knowledge is produced for the edifice, which is generally buried and invisible before excavation. Excavation, documentation and research are among main tools for producing scientific knowledge about heritage buildings and sites. In this process, the archaeologist or heritage professional generally considers some meaning that the heritage building or site might have had in the past. The cases mentioned above indicate that even though a heritage building has been interpreted and reshaped according to the views of experts, scientific knowledge production may continue. Therefore, conjecture can arise in the interpretations in contrary to the emphasis given in the Venice Charter. Thus, the production of scientific knowledge is an ongoing process.

Second, any meaning and message about the heritage site has not been inherited; rather, it is based on the views and interpretations of people, especially archaeologists and heritage professionals. Here, the main question is "why should experts such as archaeologists and heritage professionals be the only people to control this interpretation?" On one hand, Smith's explanation that the suitability of professional experts to care for and protect monuments and sites is signified by the authorising institutions of heritage (Smith, 2006, 92) is apparent. On the other, these analyses indicate that archaeological knowledge about a heritage building can change with time and that the interpretation of the experts is based on the archaeological knowledge of a particular time; in addition, this interpretation can be conjectured in time, contrary to the principle that restoration "...must stop, where conjecture begins" (Venice Charter, 1964: article 9). Therefore, the mutability of archaeological knowledge in time can act against the assertion given in article 15 "...to reveal the monument without ever distorting meaning" (Venice Charter, 1964). This implies that the meaning can also be changed from expert to expert. This finding also brings the question, "does a particular meaning exist?" for heritage buildings and sites from different historical periods that are located in a variety of world locations. In this respect, there is a need to reconsider why non-experts and different stakeholders are excluded. In other words, why everyone, alone or collectively, having the right to benefit from the cultural heritage and to contribute towards its enrichment (Faro, 2005, article 4), is excluded has to be questioned.

Third, many factors such as values, the extent of surviving architectural elements, and their potential for re-assembly and re-erection (Şimşek, 2009, 134-139) are decisive in interpreting heritage buildings and sites. The meanings given to a particular heritage building or site defines its appearance. For instance, the Celsus Library was shaped as a standing monument with its two-storey east façade constructed in accordance with the emphasis on the façade characteristics and the stone workmanship that resembled imperial structures in Rome (Strocka, 1979: 814-15). In this respect, the way a heritage building or site is interpreted refers to the way in which it is physically and conceptually intervened and shaped in the present. This also implies that a heritage building or site that is physically and conceptually shaped in the present is transmitted to future generations with these qualities. Thus, this interpretation becomes part of future life.

Fourth, the interventions conducted on a heritage building or sites reflect the material representation of the images, thoughts and feelings of interested parties. This means that both the heritage building and the site are not simply representations of past human experiences but are also the product of present human activities. Heritage buildings and sites, where values and meanings are represented and which are physically altered and shaped, are newly formed. Although the intention held with respect to some edifices is to document past uses (e.g., with Terrace House II), in others, the focus is on the architectural characteristics and aesthetic qualities of the edifice, which may be different for each case. 
Fifth, in addition to the common way of using archaeological sites for tourism, the insertion of new functions into heritage buildings and sites also forms part of the discussion in heritage discourses (Charter on the Use of Ancient Places of Performance, 1997; Haddad, 2007). Visiting heritage buildings and sites is generally seen as a leisure activity. However, the insertion of new functions into heritage buildings and sites is important for identifying experiences and memories of shared experiences. For instance, I have my own memories of the hall of the Celsus Library, where I obtained information about the building and talked it with other visitors, and of the Great Theatre, where I attended a music concert. Therefore, the visitors participate in contemporary events in heritage buildings and sites and are not simply passive consumers. The visitors each have their own stories that can be told. This implies that heritage acts as a cultural tool and as a tool for constructing a sense of place. Therefore, the use of heritage buildings or sites is a multi-layered issue. The above analysis indicates that the levels of use and the multi-layered characteristics that are present may differ. Therefore, the insertion of new uses into ancient places, which has its own emotional power to create memories and construct a sense of place, is an important part of this process.

The above arguments may appear to rest on some minor examples rather than an exhaustive list because other examples may be added. However, the results clearly indicate the fundamental complexity behind the process.

\section{Concluding Thoughts}

This paper intends to examine the process of making "heritage" and to discuss what this process is all about, how it is shaped and the identity of the actors. The analyses of cases from the archaeological site studied here, Ephesus, have shown that this process shapes and defines heritage buildings and sites in terms of its appearance, meaning and function after being subjected to interventions. This means that the process that starts with producing knowledge about heritage buildings and sites using tools such as excavation initiates a new lifecycle in which a new appearance, meaning and uses for heritage buildings and sites are defined. The emergence of a variety of factors and rationales can be seen behind this. Although heritage buildings and sites, as products and tangible parts of this process, differ in terms of appearance, function and meaning, the ways in the process is constructed and framed have commonalities. Thus, on the one hand, this process can be defined as a formation process in which scientific knowledge, appearance, meaning and new functions of heritage buildings and sites are defined and constructed. This process is both unique and unrepeatable (Şimşek, 2009: 142). On the other hand, it is a process throughout which, contemporary people and/or society interacts with past and transform past for their current uses.

In the first phase of this process, the main intention is to document, understand and interpret the remains and fragments of the past under study. In the case of archaeological edifices, the main tool that initiates this phase and the process as a whole is excavation, which is also widely explained as an unrepeatable action. However, the above analyses indicate that unlike unrepeatable characteristics of excavation, the process of scientific knowledge production may continue and can be repeated again and again in time.

After this phase, the interventions used for interpretation and presentation (including a combination of various practices, such as conservation, consolidation, re-erection), which directly affect the appearance and meaning of heritage buildings and sites, represent another phase in the process. Explanation of the new meaning(s), which need to be preserved and transmitted to future generations, is the central issue of this phase. As shown in the above five cases, some emphasis was created during past periods, and this emphasis, which lead experts to study heritage buildings, may be lost. New meanings that are attributed by interpreters are added during this phase. The above analyses also demonstrate that these interpretations are generally based on the aesthetic and historic values signified through the Venice Charter (article 9). Thus, heritage buildings generally become standing monuments 
representing artistic, aesthetic and historical values. This phase, in which meanings are signified, can be considered as an explanatory and interpretive phase.

During this process, the production of scientific knowledge can be repeated, regardless of whether the heritage building in question is interpreted and intervened. The above analysis demonstrates that scientific knowledge, especially archaeological knowledge, can change with time. Thus, intervened heritage buildings, as interpreted and presented products, can be conjectured differently as new knowledge becomes available. Production of new knowledge is part of this process. This indicates that there the potential to conjecture generally exists. Undoubtedly, expert knowledge is valuable for interpreting and understanding past. However, there is no need to exclude non-experts and other actors in community from this process to prevent conjecture.

This is a process through which the use of heritage buildings and sites are re-defined in the contemporary socio-cultural context. As shown by Terrace House II, heritage buildings and areas are products of both past and present human activities, and a process exists by which they are redefined, reshaped and re-used. Here, "use" refers to a multi-layered concept ranging from the use of a site for scientific purposes to the use of heritage buildings for performances. This means that heritage buildings become part of the socio-cultural life of contemporary society, and new types of use and new functions can be defined for them. Thus, new uses that are defined for heritage buildings or sites contribute to creating communities' own memories and to constructing a sense of place. Therefore, everyone, alone or collectively, have the right to participate this process in order to benefit from the cultural heritage and its conservation and sustainable use for human development and a better quality of life (Faro Convention, 2005).

In the context explained above, there is a necessity to view the process as a 'new formation process' in order to re-assess the decisions, decision-makers and the level of validity of some assertions given by authorised institutions. This will allow us to avoid viewing interventions as independent from each other but to view them rather as tools for the process of making "heritage". Today, the interventions, as part of a management plan shared by various stakeholders, indicate a move away from individual actions and exclusive opinions to a more holistic perspective. However, few attempts are made to include non-expert views in the interpretation of heritage buildings and sites. If we conceive of 'heritage' making as a process rather than as a building or a place and if we acknowledge that heritage buildings and sites are 'continuously constructed' and defined in relation to the contemporary sociocultural context, we might be able to identify strategies for embodying views of non-experts and diverse stakeholders. Thus, it is possible to solve some issues such as ownership and ignorance and to respond to communities warranting their inclusion. Importantly, this idea brings with it the assertion that people are active participants of this process and that decisions related to heritage buildings and sites are significant for them.

\section{REFERENCES}

AURENHAMMER, M. (2004). Sculptures of Gods and Heroes from Ephesos. In H. Koester (Ed.), Ephesos Metropolis of Asia, An Interdisciplinary Approach to its Archaeology Religion and Culture (pp. 251-280). PA: Trinity International Press.

BAMMER, A. (1972-75.) Architektur. Jahreshefte Des Österreichischen Archäologischen Institutes, L, 381-406.

BAMMER, A. (1972-75). Die politische Symbolik des Memmiusbaues. Jahreshefte Des Österreichischen Archäologischen Institutes, 20, 220-222.

BAMMER, A. \& ALZINGER, W. (1971). Das Mausoleum des C. Memmius. Forschungen in Ephesos, VII. 
COUNCIL of EUROPE. (2005). Council of Europe Framework Convention on the Value of Cultural Heritage for Society (Faro Convention).

Retrieved from Council of website: http://conventions.coe.int/Treaty/en/Treaties/Html/199.htm.

DAVID, M. \& DAVID, P.G. (1972-75). Restaurierungarbeiten von 1965-1970. Jahreshefte Des Österreichischen Archäologischen Institutes, L, 525-558.

DİNÇER, İ. \& ENLİL, Z. (2012). Kültürel Mirasın Değişen Kapsamı ve Kültürel Mirasın Toplum İçin Değeri- Faro Sözleşmesi'nin Algılanması: Türkiye İçin Bir Ön Araştırma, Kültür Politikalarl ve Yönetimi, Y1ll1k 2011, 47-56.

FAIRCLOUGH, G. (2012). Mirasın Gelecek İçin Değeri. Kültür Politikaları ve Yönetimi, Yıllık 2011, $35-44$.

GRAHAM, B.B.J. (2002). Heritage as Knowledge: Capital or Culture. Urban Studies, 39 (5-6), 1003 1017.

GRAHAM, B. B.J., ASHWORTH, G.J. \& TUNBRIDGE, J.E. (2000). A Geography of Heritage: Power, Culture and Economy, London: Arnold Publishers.

GRAHAM, B. \& HOWARD, P. (n.d.). Heritage and Identity. Retrieved from http://www.lundhumphries.co.uk/pdf/SamplePages/Ashgate_Research_Companion_to_Heritage_and_ Identity_Intro.pdf

HADDAD, N. (2007). Criteria for the Assessment of the Modern Use of Ancient Theatres and Odea. International Journal of Heritage Studies, 13(3), 265-280.

HARDY, D. (1988). Historical Geography and Heritage Studies. Area, 20 (4), 333-338.

HARRISON, R. \& SCHOFIELD, J. (2010). After Modernity, Archaeological Approaches to the Contemporary Past, New York: Oxford University Press.

HARVEY, D.C. (2001). Heritage pasts and heritage presents: Temporality, meaning and the scope of heritage studies. International Journal of Heritage Studies, 7 (4), 319-338.

HUEBER, F. (1973). Bericht über die Wiederaufrichtungsarbeiten an der Celsusbibliothek, und über die Bisheringen Ergebnisse der Untersuchung der Bausubstanz. In E. Akurgal (Ed.), The Proceedings of the Xth International Congress of Classical Archaeology Ankara-İzmir, 23-30/IX/1973 (979-987). Ankara-Izmir: Türk Tarih Kurumu.

HUEBER, F., ERDEMGİL, S. \& BÜYÜKKOLANCI, M. (eds.) 1997. Ephesos Gebaute Geschichte, Mainz am Rhein: Zabern.

ICOMOS. (1964). International Charter for the Conservation and Restoration of Monuments and Sites (The Venice Charter). Retrieved from ICOMOS website:

http://www.international.icomos.org/charters/venice_e.pdf

ICOMOS. (1990). Charter for the Protection and Management of the Archaeological Heritage (Lausanne 1990). Retrieved from ICOMOS website: http://www.international.icomos.org/charters/arch_e.pdf.

The First International Congress of Architects and Technicians of Historic Monuments (1931). The Athens Charter for the Restoration of Historic Monuments. Retrieved from ICOMOS website: 
http://www.icomos.org/index.php/en/charters-andtexts?id=167:the-athens-charter-for-the-restorationof-historicmonuments\&catid=179: charters-and-standards.

ICOMOS. (1994). The Nara Document on Authenticity (Nara 1994). Retrieved from ICOMOS website: http://www.icomos.org/charters/nara-e.pdf.

KEIL, J. (1964). Ephesos: Ein Führer Durch Die Ruinenstätte und ihre Geschichte, Wien: Österreichisches archäologisches Institut.

KRIZINGER, F., OUTSCHAR, U. \& WIPLINGER, W. (2000). The Terrace House 2. In P. Scherrer (Ed.) Ephesos: The New Guide (pp.106-113). Turkey: Ege Yayınları.

KRINZINGER, F. (2000). Das Hanghaus 2 als archäologische Herausforderung, Terrace House 2 as an Archaeological Challange, Yamac Ev 2'nin Arkeolojik Önemi. In F. Krinzinger (Ed.) Ein Dach Für Ephesos: Der Schutzbau für Das Hanghaus 2, A Roof for Ephesos: The Shelter for Terrace House 2, Efes icin bir Çatı: Yamaç Ev 2 Koruma Binası (pp.15-32). Wien: Österreichisches Archäologisches Institute.

KRINZINGER, F. (2006). The Terrace Houses in Ephesos, The New Shelter. In Z. Ahunbay and Ü. İzmirligil (Eds.) Management and Preservation of Archaeological Sites (pp.36-39). Istanbul: Side Foundations for Education Culture and Art.

LADSTATTER, S. (2002). Die Chronologie des Hanghauses 2. In F. Krinzinger and E. Christof (Eds.) Das Hanghouse 2 von Ephesos: Studien zu Baugeschichte und Chronologie (pp.9-40). Wien: Österreichischen Akademie der Wissenschaften.

LADSTÄTTER, S. (2012). Ephesos Yamac Ev 2: Arkeolojik Bir Rehber. Istanbul: Ege Yayınları. Ladstätter

LOWENTHAL, D. (1998). Heritage Crusade and the Spoils of History, second edition. Cambridge: Cambridge University Press.

MILTNER, F. (1959). XXII. Vorlaufiger Bericht über die Ausgrabungen in Ephesos. Jahreshefte Des Österreichischen Archäologischen Institutes, XLIV, 243-314.

OUTSCHAR, U. (1990). Zum Monument des C. Memmius. Jahreshefte Des Österreichischen Archäologischen Institutes, 60, 57-85.

OUTSCHAR, U. (1999). Zur Deutung des Hadrianstempels an der Kuretenstrasse. In H. Friesinger and F. Krinzinger (Eds.), 100 Jahre Österreichische Forschungen in Ephesos, (pp.443-48).

OUTSCHAR, U. (2000). The Memmius Monument. In P. Scherrer (Ed.) Ephesos: The New Guide, (pp.96). Turkey: Ege Yayınları.

OUTSCHAR, U. (2000). Temple of Hadrian. In P. Scherrer (Ed.) Ephesos: The New Guide, (pp.118119). Turkey: Ege Yayınları.

OUTSCHAR, U. (2000). Celsus Library. In P. Scherrer (Ed.) Ephesos: The New Guide, (pp.130-132). Turkey: Ege Yayınları.

QUATEMBER, U. (2011). Das Nymphaeum Traiani in Ephesos. Forschungen in Ephesos, XI/2.

QUATEMBER, U. (2010). The "Temple of Hadrian" on Curetes Street in Ephesus: new research into its building history. Journal of Roman Archaeology, 23, 376-394. 
Adnan Menderes University, Journal of Institute of Social Sciences, Vol.: 1, Issue: 2, (pp. 90-105)

QUATEMBER, U., THUSWALDNER, B. KALASEK, R., BREUCKMANN, B. and BATHOW, C. (2013). The Virtual and Physical Construction of the Octagon and Hadrian`s Temple in Ephesus. In H. G.Bock, W. Jäger \& M J. Winckler (Eds.) Scientific Computing and Cultural Heritage: Contributions in Computational Humanities, (pp.217-228). Heilderberg New York Dordrecht London: Springer.

SCHERRER, P. (2004). The city of Ephesos from the Roman period to Late Antiquity. In H. Koester (Ed.) Ephesos Metropolis of Asia, An Interdisciplinary Approach to its Archaeology Religion and Culture, (pp.1-26). PA: Trinity International Press.

SCHIRMER, W. (2000). Schutzbau in Ihrer Zeit, The protective Shelter in Its Time. In F. Krinzinger (Ed.) Ein Dach Für Ephesos: Der Schutzbau für Das Hanghaus 2, A Rooffor Ephesos: The Shelter for Terrace House 2, Efes icin bir Çatı: Yamaç Ev 2 Koruma Binası, (pp.33-42). Wien: Österreichisches Archäologisches Institute.

SMITH, L. (2006). The Uses of Heritage. London and New York: Routledge.

STROCKA, V. M. (1979). Efes’teki Celsus Kitaplığı Onarım Çalışmaları (translated by Coşkun Özgünel). Belleten, 43, 809-832.

ŞİMŞEK, G. (2009). Interventions on Immovable Archaeological Heritage on as a Tool for New Formation Process (Unpublished doctoral dissertation). Middle East Technical University, Ankara.

THUR, H. (2000). Nymphaeum Traiani. In P. Scherrer (Ed.) Ephesos: The New Guide, (pp.116-117). Turkey: Ege Yayınları.

THUR, H. (2000). The Processional way in Ephesos as a Place of Cult and Burial. In H. Koester (Ed.) Ephesos Metropolis of Asia, An Interdisciplinary Approach to its Archaeology Religion and Culture, (pp.157-200). PA: Trinity International Press.

Verona Charter on the Use of Ancient Places of Performance (Adopted at the International Colloquy held in Verona, August 1997). (1997) Retrieved from http://www.coe.int/t/dg4/cultureheritage/heritage/resources/Texts/Verona_EN.pdf.

WILBERG, W., THEUER, M., EICHLER, F. and KEIL, J. (1953). Die Bibliothek. Forschungen in Ephesos, 5/1.

YILDIZ, N. (2003). Antikçă̆ Kütüphaneleri: Kalıntılar ve Edebi Kaynaklar Işı̆̆̆ında Mimarileri, İçdüzenleri, Çalı̧̧ma Sistemleri Kitapların Yazımı ve Çoğaltılması. Istanbul: Arkeoloji ve Sanat Yayınları. 


\section{EKLER}

Figure 1. The Ephesus site map showing the location of the Curetes Street and five archaeological edifices applied on the map taken from Scherrer (2000).

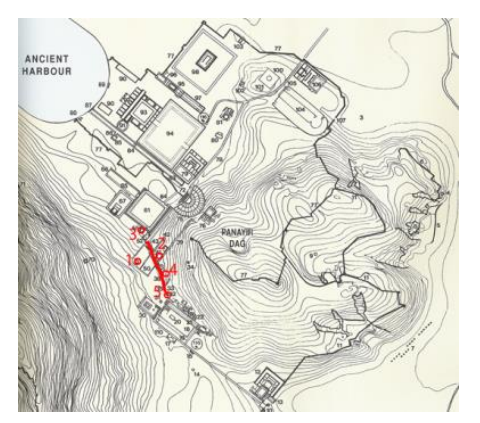

Figure 2. The Terrace House II during the excavation (Ladstätter 2012, 45).

Figure 2b. The protective shelter on the Terrace House II (Simsek, 2008).

Figure 2c. A view from the interior of the Terrace House II (Simsek, 2008).
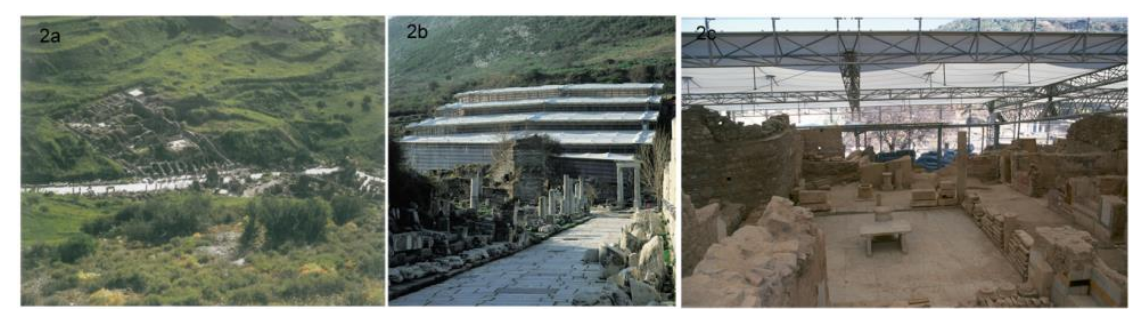

Figure 3a. The so-called Temple of Hadrian throughout excavation, 1956 (Miltner, 1959, 53-4).

Figure 3b. The proposal for the south façade of the authentic design of the so-called Temple of Hadrian (Miltner 1959, 277-8).

Figure 3c. The state of the so-called Hadrian Temple after re-erection (Simsek, 2008).
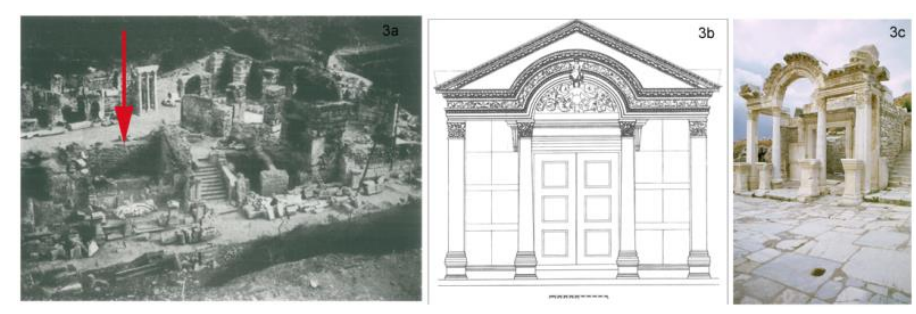
Figure 4a. The 'Parther relieves' recovered through excavation (Wilberg, Wilhelm, Max Theuer, Fritz Eichler, and Josef Keil 1953, 1).

Figure 4b. The state of the Celsus Library and Library Square after re-erection (Simsek, 2008)

Figure 4c. The interior hall of the Celsus Library and its use as a kind of information center (Simsek, 2008)

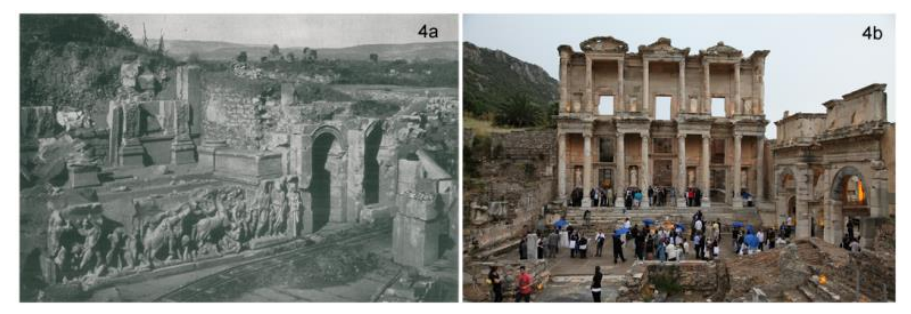

Figure 5a. The state of the Trajan Fountain in 1957 during excavation (Quatember 2011, Tafel 4).

Figure 5b. The restitution of the Trajan Fountain's façade by H. Pellionis (Quatember 2011, Tafel 5).

Figure 5c. The state of the Trajan Fountain after its re-erection (Simsek, 2008).
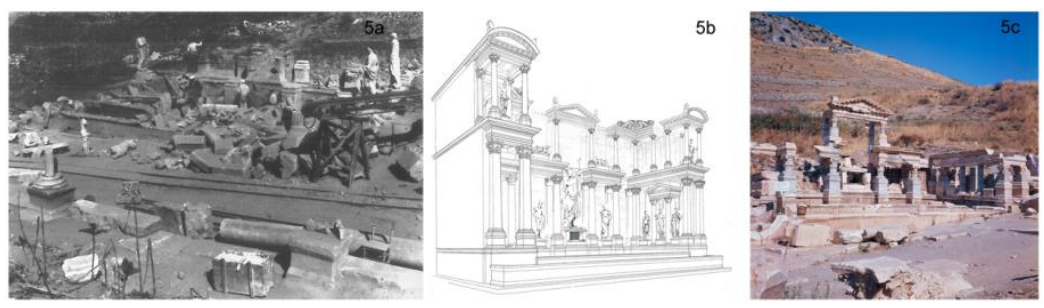

Figure 6a. The ruins of the Memmius Monument during excavation (Bammer, Anton, and Wilhelm Alzinger 1971, 13).

Figure 6b. Bammer's restitution proposal for the authentic design of the Memmius Monument (Bammer, Anton, and Wilhelm Alzinger 1971, 68).

Figure 6c. The state of the Memmius Monument after re-erection (Simsek, 2008).
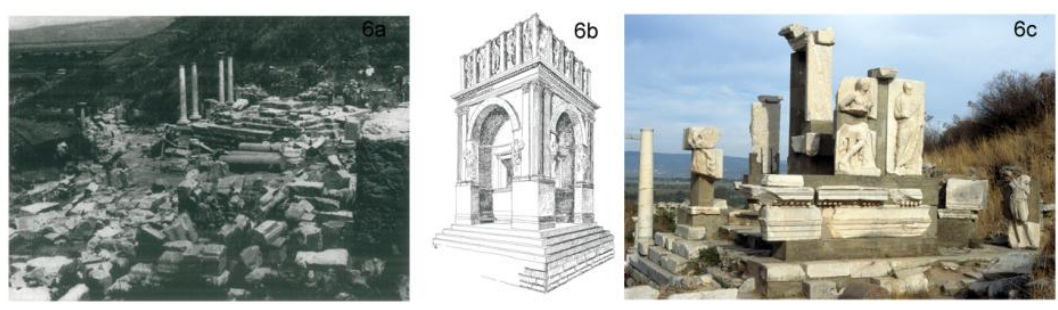